Journal of Organometallic Chemistry, 107 (1976) 23-32

() Elsevier Sequoia S.A., Lausanne - Printed in The Netherlands

\title{
SYNTHESIS AND REACTIVITY OF SOME t-BUTYL-DISILANES AND -DIGERMANES
}

\author{
K. TRIPLETT and M.D. CURTIS * \\ Department of Chemistry, The University of Michigan, Ann Arbor, MI 48104 (U.S.A.)
}

(Received May 28th, 1975)

\section{Summary}

Efficient methods of coupling $\mathrm{R}_{2} \mathrm{EHCl}(\mathrm{R}=\mathrm{Me}, \mathrm{t}-\mathrm{Bu} ; \mathrm{E}=\mathrm{Si}, \mathrm{Ge})$ to give $\mathrm{R}_{2} \mathrm{HEEHR}_{2}$ have been developed. These dihydrides are readily halogenated with $\mathrm{Br}_{2}$ or $\mathrm{I}_{2}$ to give the corresponding 1,2-dihalo-disilane or -digermane. High yields of $\mathrm{Me}_{2} \mathrm{ClGeGeClMe}$ are obtained by treating hexamethyldigermane with conc. sulfuric acid and ammonium chloride. Conc. sulfuric acid exclusively cleaves methyl groups from [t-BuMe $\left.{ }_{2} \mathrm{Ge}-\right]_{2}$ to give $[\mathrm{t}-\mathrm{BuMeClGe}-]_{2}$ after treatment with ammonium chloride. The latter dichlorodigermane is formed as a mixture of $d, l$-enantiomers and the meso isomer as shown by NMR evidence. The bulky t-butyl groups render $\left(t-\mathrm{Bu}_{4} \mathrm{Si}_{2} \mathrm{Br}_{2}\right.$ inert to nucleophilic substitution or metalhalogen exchange with organolithium reagents.

\section{Introduction}

It recently was proposed that $\mathrm{Si}=\mathrm{Si}$ double bonds might be stabilized against self-condensation if the double bond were shielded by bulky groups, e.g. $t$ butyl, on silicon [1]. As a possible route to compounds containing the $\mathrm{Si}=\mathrm{Si}$ double bond, we have considered the elimination reaction 1 , analogous to reaction 2 which is known to occur readily with 1,2-dihalo organic compounds.

$(\mathrm{t}-\mathrm{Bu})_{2} \mathrm{BrSiSiBr}(\mathrm{t}-\mathrm{Bu})_{2}+\mathrm{t}-\mathrm{BuLi} \rightarrow(\mathrm{t}-\mathrm{Bu})_{2} \mathrm{Si}=\mathrm{Si}(\mathrm{t}-\mathrm{Bu})_{2}+\mathrm{t}-\mathrm{BuBr}+\mathrm{LiBr}$

$\mathrm{BrCH}_{2} \mathrm{CH}_{2} \mathrm{Br}+\mathrm{t}-\mathrm{BuLi} \rightarrow \mathrm{CH}_{2}=\mathrm{CH}_{2}+\mathrm{t}-\mathrm{BuBr}+\mathrm{LiBr}$

We here report the details of the preparation of some new t-butyl-substituted disilanes and digermanes and note some features of their reactivity pertinent to the elimination reaction 1 . In addition, we report our results with corresponding methyl derivatives which were used initially to test certain reaction schemes. 
Results ard discussion

The diiodo derivatives, $\mathrm{IMe}_{2} \mathrm{EEMe}_{2} \mathrm{I}(\mathrm{E}=\mathrm{Si}, \mathrm{Ge})$, were prepared according to reactions $3-5$.

$2 \mathrm{Me}_{2} \mathrm{SiHCl}+\mathrm{Na} / \mathrm{K} \rightarrow \mathrm{HMe}_{2} \mathrm{SiSiMe}_{2} \mathrm{H}+\mathrm{Na} / \mathrm{KCl}$

$2 \mathrm{Me}_{2} \mathrm{GeHCl}+\mathrm{Mg}(\mathrm{Hg}) \rightarrow \mathrm{HMe}_{2} \mathrm{GeGeMe}_{2} \mathrm{H}+\mathrm{MgCl}_{2}$

$\mathrm{HMe}_{2} \mathrm{EEMe}_{2} \mathrm{H}+2 \mathrm{I}_{2} \rightarrow \mathrm{IMe}_{2} \mathrm{EEMe}_{2} \mathrm{I}+2 \mathrm{HI}$

Although $\mathrm{HMe}_{2} \mathrm{SiSiMe}_{2} \mathrm{H}$ has been previously prepared by other methods $[2,3]$, we desired a quick, direct method for preparing this dihydride from commercially available $\mathrm{Me}_{2} \mathrm{SiHCl}$. The yield of $\mathrm{HMe}_{2} \mathrm{SiSiMe}_{2} \mathrm{H}$ from reaction 3 is typically near $40 \%$. The yield was not appreciably increased by different solvents, increased reaction temperature, prolonged stirring, or changes in the disilane:metal ratio. Apparently side reactions, e.g. further coupling of the disilane, limit the yield by this method. However, the yield compares favorably with the overall yields of previous methods. Iodine reacts sluggishly with $\mathrm{HMe}_{2} \mathrm{SiSiMe}_{2} \mathrm{H}$ to give the diiododisilane, $\mathrm{IMe}_{2} \mathrm{SiSiMe}_{2} \mathrm{I}$, which is exceedingly moisture sensitive and produces voluminous clouds of HI upon contact with moist air. Due to the extreme sensitivity of this compound, satisfactory elemental analyses were not obtained, but the compound's spectroscopic properties leave little doubt of its formulation. No $\mathrm{Si}-\mathrm{H}$ stretch is observed in the IR and a single, sharp methyl resonance is found in the NMR spectrum. In addition to the parent ion at $m / e$ 270 , fragment ions with $m / e$ corresponding to $\mathrm{Me}_{2} \mathrm{SiSiIMe}_{2}{ }^{+}$and $\mathrm{Me}_{2} \mathrm{SiI}^{+}$were observed in the mass spectrum. A mass spectrum of the viscous oil which results from the air hydrolysis of $\mathrm{IMe}_{2} \mathrm{SiSiMe}_{2} \mathrm{I}$ suggests the presence of cyclosiloxanes with $\left(\mathrm{Me}_{4} \mathrm{Si}_{2} \mathrm{O}\right)_{3}$ being the major component.

The reaction of $\mathrm{Me}_{2} \mathrm{GeHCl}$ with either sodium-potassium alloy or sodium amalgam in ether solvents gave only polymeric material. Magnesium amalgam does give the coupled product, $\mathrm{HMe}_{2} \mathrm{GeGeMe}_{2} \mathrm{H}$, according to reaction 4 . The parent ions of this digermane is not observed in its mass spectrum, but the peak corresponding to $\mathrm{Me}_{2} \mathrm{GeGeMe}_{2} \mathrm{H}^{+}$is very intense. Fragment ion peaks due to loss of methyl groups and methane were also observed. Iodine reacts much more rapidly with $\mathrm{HMe}_{2} \mathrm{GeGeMe}_{2} \mathrm{H}$ than with the analogous disilane. The parent ion, $\mathrm{IMe}_{2} \mathrm{GeGeMe}_{2} \mathrm{I}^{+}$, and the fragments, $\mathrm{IMe}_{2} \mathrm{GeGeMe}_{2}{ }^{+}$and $\mathrm{Me}_{2} \mathrm{GeI}^{+}$, were observed in the mass spectrum.

Since $\mathrm{Me}_{2} \mathrm{GeHCl}$ is not readily available, a more convenient route to 1,2 -dihalodigermanes is the adaption of Kumada's method [5] of demethylating disilanes with concentrated sulfuric acid and ammonium chloride. The demethylation of $\mathrm{Me}_{6} \mathrm{Ge}_{2}$ proceeds smoothly to give $\mathrm{ClMe}_{2} \mathrm{GeGeMe}_{2} \mathrm{Cl}$ in $87 \%$ yield (eq. 6).

$\mathrm{Me}_{6} \mathrm{Ge}_{2}+2 \mathrm{H}_{2} \mathrm{SO}_{4} \stackrel{\mathrm{NH}_{4} \mathrm{Cl}}{\longrightarrow} \mathrm{ClMe}_{2} \mathrm{GeGeMe}_{2} \mathrm{Cl}+2 \mathrm{CH}_{4}+2 \mathrm{NH}_{4} \mathrm{HSO}_{4}$

Cleavage of phenyl groups from $\mathrm{PhMe}_{2} \mathrm{GeGeMe}_{2} \mathrm{Ph}$ with $\mathrm{HCl}$, and the redistribution of methyl groups on $\mathrm{Me}_{6} \mathrm{Ge}_{2}$ with $\mathrm{SnCl}_{4}$ [6] have previously been used to prepare 1,2-dichlorotetramethyldigermane, but these procedures are not as convenient as the sulfuric acid cleavage reported here.

We have prepared $\mathrm{Me}_{6} \mathrm{Ge}_{2}$ in $60 \%$ yield by coupling $\mathrm{Me}_{3} \mathrm{GeCl}$ with molten 
potassium in refluxing cyclohexane. The use of magnesium amalgam in THF was also investigated as a coupling reagent. In addition to hexamethyldigermane (45\%), we also obtained a $15 \%$ yield of $\left(\mathrm{Me}_{3} \mathrm{Ge}\right)_{2} \mathrm{Hg}$ [7]. In situ transmetallation of the mercury compound with lithium ribbon, followed by the addition of more $\mathrm{Me}_{3} \mathrm{GeCl}$, gave an overall $62 \%$ yield of $\mathrm{Me}_{6} \mathrm{Ge}_{2}$ (eq. 7,8 ). :

$\left(\mathrm{Me}_{3} \mathrm{Ge}\right)_{2} \mathrm{Hg}+2 \mathrm{Li} \rightarrow 2 \mathrm{Me}_{3} \mathrm{GeLi}+\mathrm{Hg}$

$\mathrm{Me}_{3} \mathrm{GeLi}+\mathrm{Me}_{3} \mathrm{GeCl} \rightarrow \mathrm{Me}_{6} \mathrm{Ge}_{2}+\mathrm{LiCl}$

The synthesis of digermanes incorporating t-butyl groups was accomplished via reactions 9 and 10 .

$2 \mathrm{t}-\mathrm{BuMe}_{2} \mathrm{GeCl}+2 \mathrm{~K} \rightarrow \mathrm{t}-\mathrm{BuMe}_{2} \mathrm{GeGeMe}_{2} \mathrm{t}-\mathrm{Bu}+2 \mathrm{KCl}$

$\mathrm{t}-\mathrm{BuMe}_{2} \mathrm{GeGeMe}_{2} \mathrm{t}-\mathrm{Bu}+\mathrm{H}_{2} \mathrm{SO}_{4} \stackrel{\mathrm{NH}_{4} \mathrm{Cl}}{\longrightarrow}[\mathrm{Cl}(\mathrm{t}-\mathrm{Bu}) \mathrm{MeGe}-]_{2}$

The 1,2-di(t-butyl)tetramethyldigermane was obtained in only $43 \%$ yield, compared to a $60 \%$ yield for $\mathrm{Me}_{6} \mathrm{Ge}_{2}$ under comparable conditions. The lower yield may be due to the steric bulk of the t-butyl groups. No steric effects were noted in the demethylation reaction 10 since the chlorinated digermane was obtained in high yield. No evidence was obtained for cleavage of the t-butyl groups by sulfuric acid, although $\mathrm{Ge}-\mathrm{Ge}$ bond cleavage did occur to a slight degree.

The 1,2-dichloro-1,2-di(t-butyl)dimethyldigermane so obtained is a mixture of $d$, l-enantiomers and the meso form as shown by the NMR spectrum in Fig. 1. The t-butyl resonances are separated by only $0.8 \mathrm{~Hz}$ and are resolved only in expanded sweep widths, but the methyl resonances of the enantiomers and the

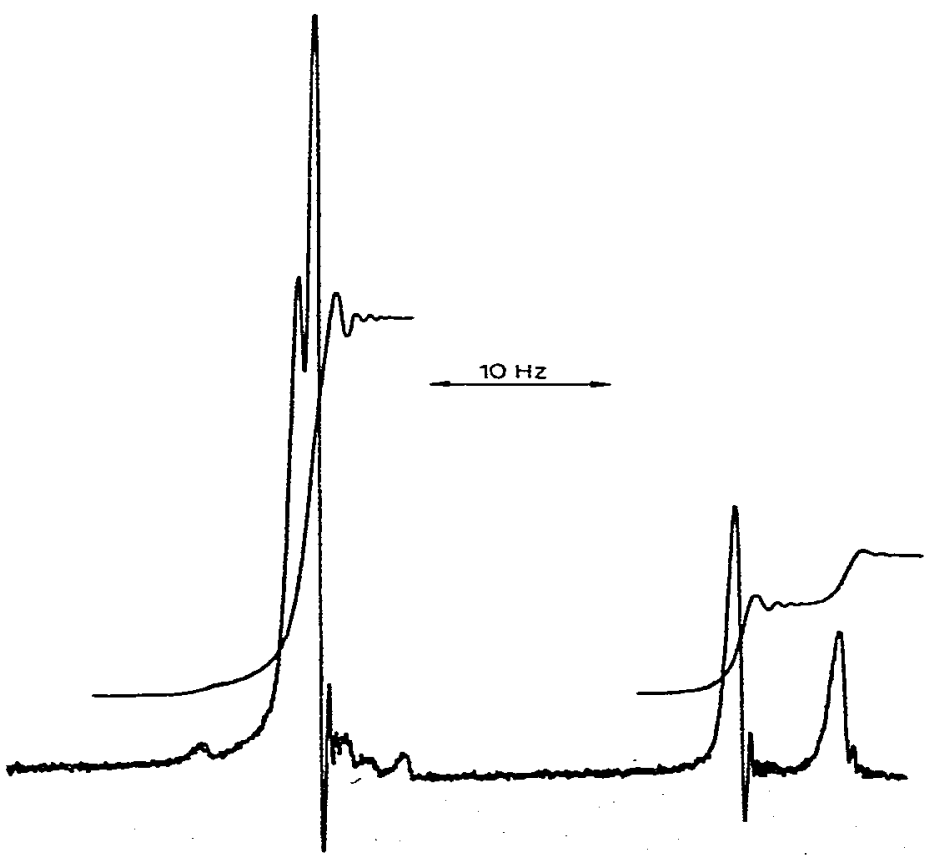

Fig. 1. Proton NMR sfectrum of the mixture of $d, l$-enantiomers and meso isomer of [(t-Bu)MeClGe- ${ }_{2}$. 
meso form differ by $5.8 \mathrm{~Hz}$ and are easily resolved. It is not possible at this time to assign the peaks to a specific stereoisomer. A completely random formation of [ $\mathrm{Cl}(\mathrm{t}-\mathrm{Bu}) \mathrm{MeGe}-]_{2}$ would result in a 1:1 ratio of $d, l$-pair to meso isomer, so the spectrum shows a preferential formation of one isomer over the other. Féher and Plichta [8] have previously reported an NMR differentiation of sterecisomeric digermanes.

The preparation of $\mathrm{Br}(\mathrm{t}-\mathrm{Bu})_{2} \mathrm{SiSi}(t-\mathrm{Bu})_{2} \mathrm{Br}$ was planned according to reactions 11-15.

$\mathrm{SiCl}_{4}+2 \mathrm{t}-\mathrm{BuLi} \rightarrow(\mathrm{t}-\mathrm{Bu})_{2} \mathrm{SiCl}_{2}$

$(\mathrm{t}-\mathrm{Bu})_{2} \mathrm{SiCl}_{2}+\mathrm{LiAlH}_{4} \rightarrow(\mathrm{t}-\mathrm{Bu})_{2} \mathrm{SiH}_{2}$

$(\mathrm{t}-\mathrm{Bu})_{2} \mathrm{SiH}_{2}+\mathrm{HgCl}_{2} \rightarrow(\mathrm{t}-\mathrm{Bu})_{2} \mathrm{SiHCl}$

$2(\mathrm{t}-\mathrm{Bu})_{2} \mathrm{SiHCl}+2 \mathrm{~K} \rightarrow \mathrm{H}(\mathrm{t}-\mathrm{Bu})_{2} \mathrm{SiSi}(\mathrm{t}-\mathrm{Bu})_{2} \mathrm{H}$

$\mathrm{H}(\mathrm{t}-\mathrm{Bu})_{2} \mathrm{SiSi}(\mathrm{t}-\mathrm{Bu})_{2} \mathrm{H}+2 \mathrm{Br}_{2} \rightarrow\left[\mathrm{Br}(\mathrm{t}-\mathrm{Bu})_{2} \mathrm{Si}-\right]_{2}+2 \mathrm{HBr}$

$\mathrm{Di}(\mathrm{t}$-butyl)dichlorosilane was readily reduced to di(t-butyl)silane with lithium aluminum hydride. The dihydride, however, was completely inert to $\mathrm{HgCl}_{2}$ even in refluxing toluene. This is in sharp contrast to unhindered diorganosilanes. A molar equivalent of bromide readily gave bromodi(t-butyl)silane in quantitative yield according to reaction 16.

$(\mathrm{t}-\mathrm{Bu})_{2} \mathrm{SiH}_{2}+\mathrm{Br}_{2} \rightarrow(\mathrm{t}-\mathrm{Bu})_{2} \mathrm{SiHBr}+\mathrm{HBr}$

We then discovered that a slight modification of Sommer's preparation [9] of $(t-B u)_{2} \mathrm{SiCl}_{2}$ gave good yields of $(\mathrm{t}-\mathrm{Bu})_{2} \mathrm{SiHCl}$ directly from $\mathrm{t}-\mathrm{BuLi}$ and $\mathrm{SiCl}_{4}$ (see Experimental). In addition to $(t-B u)_{2} \mathrm{SiHCl}$, smaller amounts of $(\mathrm{t}-\mathrm{Bu})_{2} \mathrm{SiH}_{2}$ and $(\mathrm{t}-\mathrm{Bu})_{2} \mathrm{SiCl}_{2}$ are also obtained. After submission of this manuscript, other workers [10] reported the formation of silyl hydrides in the reaction of $t-B u L i$ with $\mathrm{SiCl}_{4}$. Hydride formation has also been observed with other bulky organolithium reagents $[11,12]$. Under our conditions (prolonged reflux in cyclohexane), the hydrides could be formed by three possible mechanisms:

(a) $\beta$-hydrogen shift during the reaction of $(\mathrm{t}-\mathrm{Bu})_{2} \mathrm{SiCl}_{2}$ with a third mole equivalent of $\mathrm{t}$-BuLi.

(b) metallation of solvent to give $\mathrm{C}_{6} \mathrm{H}_{11} \mathrm{Li}$, followed by $\beta$-hydrogen shift as in eq. 9.

(c) decomposition of $\mathrm{RLi}$ to $\mathrm{LiH}$ and alkene, followed by the reduction of $\mathrm{Si}-\mathrm{Cl}$ bonds by $\mathrm{LiH}$ to $\mathrm{Si}-\mathrm{H}$.

The coupling of $(\mathrm{t}-\mathrm{Bu})_{2} \mathrm{SiHCl}$ with molten potassium in refluxing cyclohexane resulted mainly in the formation of the desired dihydride, $\mathrm{H}(\mathrm{t}-\mathrm{Bu})_{2} \mathrm{SiSi}(\mathrm{t}-\mathrm{Bu})_{2} \mathrm{H}$. This coupling reaction was unique in all that we performed in that the reaction mixture turns red. A similar red color has been observed in the reaction between (i-Pr) ${ }_{3} \mathrm{GeCl}$ and sodium - potassium alloy [13]. These red colors presumably are due to $(\mathrm{t}-\mathrm{Bu})_{2} \mathrm{SiHK}$ and $(\mathrm{i}-\mathrm{Pr})_{3} \mathrm{GeK}$ which are formed faster than they react with the sterically hindered halides.

The bromination of $\left[\mathrm{H}(\mathrm{t}-\mathrm{Bu})_{2} \mathrm{Si}-\right]_{2}$ by bromine to form $\left[\mathrm{Br}(\mathrm{t}-\mathrm{Bu})_{2} \mathrm{Si}-\right]_{2}$ (reaction 15) occurs in quantitative yield at $-20^{\circ} \mathrm{C}$, at which temperature no $\mathrm{Si}-\mathrm{Si}$ bond cleavage was observed. 


\section{Reactivity of $\mathrm{XR}_{2} \mathrm{EER}_{2} \mathrm{X}$}

The behavior of the above aihalo-disilanes and -digermanes with various alkyllithium reagents has been investigated. In some experiments, 1,3-dienes were present as trapping agents. It was hoped that the $R_{2} X E E X R_{2}$ species would lose halogen according to eq. 1 , and the resulting alkene analog would react with the dienes via eq. 17.

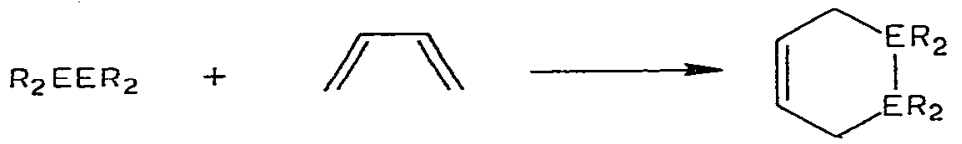

The bulky $t$-butyl groups render $(t-B u)_{2} \operatorname{BrSiSiBr}(t-B u)_{2}$ exceedingly inert toward alkyllithium and other reagents. No reaction was observed with lithium, sodium, or magnesium amalgams at room temperature in THF medium. With molten potassium in refluxing cyclohexane, $\left[(\mathrm{t}-\mathrm{Bu})_{2} \mathrm{BrSi}-\right]_{2}$ formed a viscous polymer, which was not investigated in detail, and small amounts of $(t-B u)_{3}-$ $\mathrm{Si}_{2} \mathrm{H}_{3}$ and $(\mathrm{t}-\mathrm{Bu})_{3} \mathrm{Si}_{2} \mathrm{H}_{3} \mathrm{O}(2: 0.75)$. t-Butyllithium failed to react with this disilane in refluxing petroleum ether $\left(30-60^{\circ} \mathrm{C}\right)$. Similarly, n-butyllithium, its tetramethylethylenediamine complex, and methyllithium failed to react with $\left[(t-B u)_{2} \mathrm{BrSi}-\right]_{2}$. The dibromosilane was also recovered unchanged after stirring for $24 \mathrm{~h}$ with $\mathrm{Na}_{2} \mathrm{Fe}(\mathrm{CO})_{4}$ in THF.

The digermane, $\mathrm{Me}_{2} \mathrm{ClGeGeClMe}_{2}$, also failed to react with t-BuLi at -60 to $-40^{\circ} \mathrm{C}$ in either petroleum ether $\left(30-60^{\circ} \mathrm{C}\right)$ or ethyl ether. Upon gradually warming these mixtures to room temperature, lithium chloride precipitated. From the petroleum ether, large quantities of polymer, and small amounts of distillable liquid could be isolated. The distillable liquid consisted of (t-Bu) $\mathrm{Me}_{2}-$ $\mathrm{GeGeMe}_{2}(\mathrm{t}-\mathrm{Bu})$ and $\mathrm{HMe}_{2} \mathrm{GeGeMe}_{2}(\mathrm{t}-\mathrm{Bu})$ (ca. 2:1) and trace quantities of (t-Bu) $\mathrm{Me}_{2} \mathrm{GeGeMe}_{2} \mathrm{Cl}$ and $\mathrm{HMe}_{2} \mathrm{GeGeMe}_{2} \mathrm{H}$. These results were essentially unchanged when 1,3-dienes, e.g. cyclohexa-1,3-diene, or trans, trans-2,4-hexadiene were initially present.

The production of large quantities of polygermanes in the above reactions may indicate the formation of $\mathrm{Me}_{2} \mathrm{Ge}=\mathrm{GeMe}_{2}$ which immediately polymerizes even in the presence of a trapping agent; but other mechanisms can also account for the polymer. In view of the lack of reactivity of $\left[\mathrm{Me}_{2} \mathrm{ClGe}-\right]_{2}$ toward $t-\mathrm{BuLi}$ at low temperatures, the reactivity of $[\mathrm{Cl}(\mathrm{t}-\mathrm{Bu}) \mathrm{MeGe}-]_{2}$ was not investigated.

Sodium tetracarbonylferrate, $\mathrm{Na}_{2} \mathrm{Fe}(\mathrm{CO})_{4}$, does react with $\mathrm{ClMe}_{2} \mathrm{GeGeMe}_{2} \mathrm{Cl}$ to give cyclic 5- and 6-membered rings, e.g.:

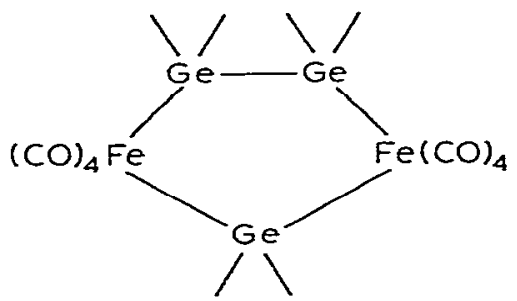

and

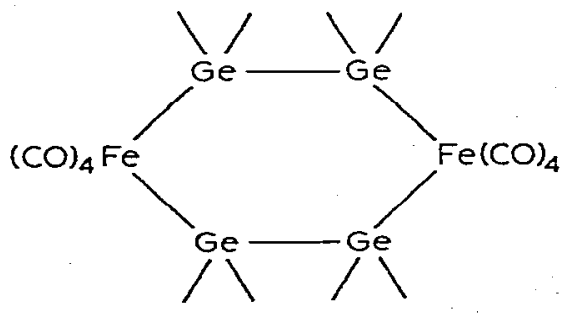

These results are reported elsewhere [14]. 


\section{Experimental}

Infrared spectra-were obtained on a Perkin-EImer 457 grating spectrometer. Proton NMR spectra were recorded on a Varian T-60 with benzene or chloroform as internal standards. Mass spectra were obtained on an AEI MS902 instrument using the direct inlet probe. GLC-mass spectra were obtained on an AEI MS30 double beam, double focusing spectrometer interfaced with a Digital PDP8/m computer and a PYE series 104 Chromatogram. Elemental analyses were performed by Galbraith Laboratories, Inc., Knoxville, Tenn: and Spang Microanalytical Laboratory, Ann Arbor, Mi. Unless specified otherwise, all operations were conducted under a nitrogen atmosphere. The t-butyllithium reagent was $0.75 M$ in n-pentane and was purchased from Alpha Products, Beverly, Mass.

\section{1,1,2,2-Tetramethyldisilane}

In a dry, three-necked, 250-mI flask equipped with a reflux condenser, equal pressure dropping funnel, and a glass * covered magnetic stirring bar were placed $0.075 \mathrm{~mol}$ of sodium and $0.15 \mathrm{~mol}$ of potassium. These metals were stirred together until the liquid amalgam was formed. Then $100 \mathrm{ml}$ of dry ethyl ether was added, followed by the dropwise addition of dimethylchlorosilane $(0.127 \mathrm{~mol})$. A white coating appeared immediately on the alloy, and after about $1 \mathrm{~h}$ of stirring, a gentie reflux commenced and the mixture darkened. After ca. $2 \mathrm{~h}$ the mixture was filtered, giving a dark, pyrophoric powder and a clear filtrate. Fractional distillation of the filtrate yielded $3 \mathrm{~g}(40 \%)$ of 1,1,2,2-tetramethyldisilane, b.p. $86-87^{\circ} \mathrm{C}$ (lit. [2] $86-87^{\circ} \mathrm{C}$ ). IR $\left(\mathrm{CCl}_{4}\right): \nu(\mathrm{Si}-\mathrm{H}) 2100 \mathrm{~cm}^{-1} . \mathrm{NMR}\left(\mathrm{CCl}_{4}\right): \mathrm{Me}$, doublet $(J 5 \mathrm{~Hz})$ at $\tau 9.83 ; \mathrm{H}$, multiplet at $\tau$ 6.30. Parent ion at $\mathrm{m} / \mathrm{e} 118$.

\section{1,1,2,2-Tetramethyl-1,2-diiododisilane}

Iodine $(9.15 \mathrm{~g}, 0.036 \mathrm{~mol})$, dissolved in $250 \mathrm{ml}$ of dichloromethane, was slowly added with stirring to $2.1 \mathrm{~g}(0.018 \mathrm{~mol})$ of tetramethyldisilane dissolved in ca. $50 \mathrm{ml}$ of dichloromethane at $0^{\circ} \mathrm{C}$. At this temperature, the reaction appeared to be very sluggish, so the mixture was refluxed for $18 \mathrm{~h}$. The still dark mixture was then concentrated and filtered to remove the iodine which crystallized. The solution was then treated with antimony powder to remove unreacted iodine. The solvent was then replaced with petroleum ether $\left(30-60^{\circ} \mathrm{C}\right)$, and subsequent cooling to $-60^{\circ} \mathrm{C}$ gave a crop of yellow crystals. After sublimation, $4.1 \mathrm{~g} \mathrm{(61 \% )}$ of white product, m.p. $68-70^{\circ} \mathrm{C}$, was obtained. $\mathrm{NMR}\left(\mathrm{CCI}_{4}\right): \tau 9.07$. Parent ion at $m / e$ 370. (Found: $\mathrm{C}, 12.99 ; \mathrm{H}, 3.24 . \mathrm{C}_{4} \mathrm{H}_{12} \mathrm{I}_{2} \mathrm{Si}_{2}$ calcd.: $\mathrm{C}, 14.70 ; \mathrm{H}, 3.54 \%$.)

\section{1,1,2,2-Tetramethyldigermane}

Dimethylchlorogermane $(13.4 \mathrm{~g}, 0.097 \mathrm{~mol})$ was added dropwise to magnesiurn amalgam, prepared by stirring $2.0 \mathrm{~g}$ of magnesium with $100 \mathrm{~g}$ of mercury, under $50 \mathrm{ml}$ of THF in a three-necked, 250-ml flask equipped with dropping funnel, reflux condenser, and a mechanical stirrer. An exothermic reaction ensued and

\footnotetext{
* We have found that liquid sodium-potassium alloy occasionally reacts violently with Tefion (อ. presumably producing the metal fluorides and carbon.
} 
a grey precipitate formed. The mixture was stirred and heated to refiux for 60 min. After removal of the excess amalgam, the mixture was hydrolyzed with water, petroleum ether $\left(30-60^{\circ} \mathrm{C}\right)$ was added, and the organic layer separated and dried over sodium sulfate. Fractional distillation gave $3 \mathrm{~g}$ of $\mathrm{HMe}_{2} \mathrm{GeGeMe}_{2} \mathrm{H}$, b.p. $65^{\circ} \mathrm{C} / 130$ Torr. IR $\left(\mathrm{CCl}_{4}\right): \nu(\mathrm{Ge}-\mathrm{H}) 2000 \mathrm{~cm}^{-1}$. NMR $\left(\mathrm{C}_{6} \mathrm{D}_{6}\right): \mathrm{Me}$, doublet $(J 4 \mathrm{~Hz})$ at $\tau$ 9.70; $\mathrm{H}$, multiplet at $\tau$ 6.11. The ion $\mathrm{Me}_{4} \mathrm{Ge}_{2} \mathrm{H}^{+}$was observed at m/e 207. (Found: $\mathrm{C}, 23.25 ; \mathrm{H}, 6.85 . \mathrm{C}_{4} \mathrm{H}_{14} \mathrm{Ge}_{2}$ calcd.: $\mathrm{C}, 23.17 ; \mathrm{H}, 6.76 \%$.)

\section{1,1,2,2-Tetramethyl-1,2-diiododigermane}

Iodine $(1.4 \mathrm{~g}, 4.8 \mathrm{mmol})$ was added with stirring to a solution of $\mathrm{Me}_{4} \mathrm{Ge}_{2} \mathrm{H}_{2}$ $(0.6 \mathrm{~g}, 2.9 \mathrm{mmol})$ in petroleum ether $\left(30-60^{\circ} \mathrm{C}\right)$. After the iodine color disappeared, the solvent was removed, leaving an oily, white solid which was recrystallized from petroleum ether $\left(30-60^{\circ} \mathrm{C}\right)$ at $-15^{\circ} \mathrm{C}$. Sublimation of this solid gave $0.65 \mathrm{~g}(49 \%)$ of pure $\mathrm{IMe}_{2} \mathrm{GeGeMe}_{2} \mathrm{I}, \mathrm{m} . \mathrm{p} .62^{\circ} \mathrm{C}$. NMR $\left(\mathrm{C}_{6} \mathrm{D}_{6}\right): \tau$ 8.96. Parent ion at $m / e$ 460. (Found: $\mathrm{C}, 10.33 ; \mathrm{H}, 2.52 . \mathrm{C}_{4} \mathrm{H}_{12} \mathrm{Ge}_{2} \mathrm{I}_{2}$ calcd.: $\mathrm{C}, 10.45 ; \mathrm{H}$, 2.62\%.)

\section{Hexamethyldigermane}

(a) From potassium and trimethylchlorogermane. Potassium $(3.8 \mathrm{~g}, 0.098$ mol) was melted in $150 \mathrm{ml}$ of refluxing cyclohexane contained in a three-necked flask equipped with mechanical stirrer, reflux condenser, and dropping funnel. Trimethylchlorogermane $(15 \mathrm{~g}, 0.098 \mathrm{~mol})$ was then added dropsvise with rapid stirring to give a blue reaction mixture which was stirred for $2 \mathrm{~h}$ at reflux. After filtering away the blue, pyrophoric solid, fractional distillation of the filtrate yielded $7.0 \mathrm{~g}(60 \%)$ of hexamethyldigermane, b.p. $136^{\circ} \mathrm{C}$ (lit. [15] $137^{\circ} \mathrm{C} / 772$ Torr).

(b) From magnesium amalgam and trimethylchlorogermane. Trimethylchlorogermane $(10.0 \mathrm{~g}, 0.066 \mathrm{~mol})$ was added to magnesium amalgam $(1.0 \mathrm{~g} \mathrm{Mg} / 50.0 \mathrm{~g}$ $\mathrm{Hg}$ ) in $50 \mathrm{ml}$ of THF using the above described apparatus. The mixture turned green and was then heated to reflux for $2 \mathrm{~h}$. After filtration from the yellowgreen solid, the filtrate was trap-to-trap distilled to give hexamethyldigermane in $46 \%$ yield. The yellow-green powder, and the residue from the trap-to-trap distillations were extracted with petroleum ether $\left(30-60^{\circ} \mathrm{C}\right)$. Concentration and cooling of this solution yielded $2.0 \mathrm{~g}$ of bis(trimethylgermyl)mercury, m.p. $120-122^{\circ} \mathrm{C}$ (lit. [7] $120-122^{\circ} \mathrm{C}$ ). $\operatorname{NMR}\left(\mathrm{C}_{6} \mathrm{D}_{6}\right): \tau 9.70$ (lit. [7] $\tau 9.53$ ).

In a similar experiment, lithium ribbon was added to the reaction mixture after the initial exothermic reaction was complete and the excess amalgam had been removed. Trimethylchlorogermane $(2.5 \mathrm{~g})$ was then added to the caramel colored solution. Work-up as before gave a $62 \%$ yield of hexamethyldigermane.

\section{1,1,2,2-Tetramethyl-1,2-dichlorodigermane}

The procedure is adapted from that of Kumada [5]. Hexamethyldigermane $(11.0 \mathrm{~g}, 0.047 \mathrm{~mol})$ was allowed to react at room temperature with conc. sulfuric acid (48 g). After stirring for $30 \mathrm{~h}$, gas evolution had ceased and $7.7 \mathrm{~g}$ of ammonium chloride (previously dried in an Abderhalden pistol at $110^{\circ} \mathrm{C}$ under vacuum) was added in portions to the reaction mixture cooled in an ice bath. A white precipitate formed immediately. After $30 \mathrm{~min}$, of stirring, the precipitate. was dissolved in petroleum ether $\left(30-60^{\circ} \mathrm{C}\right)$. Following separation and concentra- 
tion of the organic phase, white crystals were obtained. Recrystallization from petroleum ether $\left(30-60^{\circ} \mathrm{C}\right)$ at $-15^{\circ} \mathrm{C}$ gave pure product, m.p. $45-47.5^{\circ} \mathrm{C}$, in 87\% yield. NMR $\left(\mathrm{C}_{6} \mathrm{H}_{6}\right): \tau$ 9.27. (Found: $\mathrm{C}, 17.37 ; \mathrm{H}, 4.42 . \mathrm{C}_{4} \mathrm{H}_{12} \mathrm{Cl}_{2} \mathrm{Ge}_{2}$ calcd.: C, 17.38; H, 4.35\%.)

\section{1,1,2,2-Tetramethyl-1,2-di-t-butyldigermane}

This compound was prepared by coupling $6.8 \mathrm{~g}$ of $\mathrm{t}-\mathrm{BuMe} \mathrm{C}_{2} \mathrm{GeCl}[16]$ with a 10-fold excess of potassium in the manner described for hexamethyldigermane. The reflux time was $1 \mathrm{~h}$, and the product, b.p. $48^{\circ} \mathrm{C} / 0.2$ Torr, was obtained in $43 \%$ yield. NMR $\left(\mathrm{C}_{6} \mathrm{H}_{6}\right): \mathrm{Me}, \tau 9.83 ; t-\mathrm{Bu}, \tau 9.03$. The parent ion was observed at $m / e$ 320. (Found: $\mathrm{C}, 45.20 ; \mathrm{H}, 9.36 . \mathrm{C}_{12} \mathrm{H}_{30} \mathrm{Ge}_{2}$ calcd.: $\mathrm{C}, 45.12 ; \mathrm{H}, 9.44 \%$.)

\section{1,2-Dichloro-1,2-di-t-butyl-1,2-dimethyldigermane}

The product from the above reaction $(2.8 \mathrm{~g})$ was stirred with conc. sulfuric acid at room temperature for $24 \mathrm{~h}$. Work-up following that described for $\mathrm{Me}_{4} \mathrm{Cl}_{2} \mathrm{Ge}_{2}$ yielded a few drops of $t-\mathrm{BuMe}_{2} \mathrm{GeCl}$ and $2.0 \mathrm{ml}$ of $\mathrm{Me}_{2}(\mathrm{t}-\mathrm{Bu})_{2} \mathrm{Cl}_{2} \mathrm{Ge}_{2}$, b.p. $62.5-63.5^{\circ} \mathrm{C} / 0.2$ Torr. NMR $\left(\mathrm{C}_{6} \mathrm{H}_{6}\right): \mathrm{Me}, \tau 9.22$ and $\tau 9.15 ; \mathrm{t}-\mathrm{Bu}$, two overlapping singlets at $\tau$ 8.95. Parent ion observed at m/e 360. (Found: $\mathrm{C}$, $33.59 ; \mathrm{H}, 6.74 . \mathrm{C}_{10} \mathrm{H}_{24} \mathrm{Cl}_{2} \mathrm{Ge}_{2}$ calcd.: $\mathrm{C}, 33.32 ; \mathrm{H}, 6.66 \%$.)

\section{Di-t-butylchlorosilane}

This procedure is essentially that due to Tyler et al. [9] for the preparation of $(t-B u)_{2} \mathrm{SiCl}_{2}$, except that after stirring overnight at room temperature, the mixture was quickly brought to a reflux temperature of $75^{\circ} \mathrm{C}$ by distilling off the pentane while adding cyclohexane. The reaction mixture was then refluxed at $75^{\circ} \mathrm{C}$ for 4 days. Thus, tetrachlorosilane $(0.25 \mathrm{~mol})$ and $t$-butyllithium $(0.5 \mathrm{~mol})$, gave upon work-up di-t-butylsilane $(2.0 \mathrm{~g})$, di-t-butylcnlorosilane $(21.0 \mathrm{~g})$, and di-t-butyldichlorosilane $(8.0 \mathrm{~g})$. The products were characterized as follows: (t-Bu) ${ }_{2} \mathrm{SiH}_{2}$, b.p. $48^{\circ} \mathrm{C} / 45 \mathrm{Torr} ; \nu(\mathrm{Si}-\mathrm{H})$ (neat) $2096 \mathrm{~cm}^{-1}$; NMR $\left(\mathrm{CDCl}_{3}\right): \mathrm{t}-\mathrm{Bu}, \tau$ 8.93; $\mathrm{H}, \tau$ 6.58. (Found: $\mathrm{C}, 66.27 ; \mathrm{H}, 13.71 . \mathrm{C}_{8} \mathrm{H}_{20}$ Si calcd.: $\mathrm{C}$, $66.55 ; \mathrm{H}_{8}$ 13.99.) (t-Bu) ${ }_{2} \mathrm{SiHCl}$, b.p. $38-40^{\circ} \mathrm{C} / 10$ Torr; $\nu(\mathrm{Si}-\mathrm{H})$ (neat) $2129 \mathrm{~cm}^{-1}$; NMR $\left(\mathrm{CDCl}_{3}\right): \mathrm{t}-\mathrm{Bu}, \tau$ 8.92; $\mathrm{H}, \tau$ 5.77. (Found: $\mathrm{C}, 53.77 ; \mathrm{H}, 10.83 . \mathrm{C}_{8} \mathrm{H}_{19} \mathrm{ClSi}$ calcd.: C, 53.78; $\mathrm{H}, 10.64 \%$.) (t-Bu) ${ }_{2} \mathrm{SiCl}_{2}$, b.p. $44-48^{\circ} \mathrm{C} / 0.01$ Torr (lit. [9] b.p. $190^{\circ} \mathrm{C} / 729$ Torr $)$; NMR $\left(\mathrm{CDCl}_{3}\right): \tau 8.83$.

\section{Di-t-butylbromosilane}

The reduction of di-t-butyldichlorosilane $(46.0 \mathrm{~g}, 0.22 \mathrm{~mol})$ with lithium aluminium hydride $(8.2 \mathrm{~g}, 0.22 \mathrm{~mol})$ in ethyl ether gave $16.7 \mathrm{~g}(53 \%)$ of $(\mathrm{t}-\mathrm{Bu})_{2}$ $\mathrm{SiH}_{2}$ after $12 \mathrm{~h}$ at reflux temperature. This was dissolved in $50 \mathrm{ml}$ of $\mathrm{CCl}_{4}$ and cooled to $-10^{\circ} \mathrm{C}$. Dropwise addition of bromine $(18.4 \mathrm{~g}, 0.115 \mathrm{mmol})$, dissolved in $60 \mathrm{ml}$ of $\mathrm{CCl}_{4}$, gave a pale orange solution. Fractional distillation yielded $19.7 \mathrm{~g}(78 \%)$ of $(\mathrm{t}-\mathrm{Bu})_{2} \mathrm{SiHBr}$, b.p. $52^{\circ} \mathrm{C} / 4$ Torr. NMR $\left(\mathrm{CCl}_{4}\right): \mathrm{t}-\mathrm{Bu}, \tau$ 8.87; $\mathrm{Si} \underline{\mathrm{H}}$, T 5.75. $\nu(\mathrm{Si}-\mathrm{H})$ (neat) $2130 \mathrm{~cm}^{-1} ; \nu(\mathrm{Si}-\mathrm{Br}) 450 \mathrm{~cm}^{-1}$. (Found: $\mathrm{C}, 43.08 ; \mathrm{H}$, 8.63. $\mathrm{C}_{8} \mathrm{H}_{19} \mathrm{BrSi}$ calcd.: $\mathrm{C}, 43.04 ; \mathrm{H}, 8.60 \%$.)

\section{1,1,2,2-Tetra-t-butyldisilane}

This compound was prepared from $15 \mathrm{~g}$ of $(\mathrm{t}-\mathrm{Bu})_{2} \mathrm{SiHCl}$ and an equimolar quantity of potassium by the procedure outlined for hexamethyldigermane. 
The mixture was refluxed for $3 \mathrm{~h}$ and became caramel-colored. Filtration gave a red solution which was fractionally distilled to give (t-Bu) ${ }_{4} \mathrm{Si}_{2} \mathrm{H}_{2}$, b.p. $75^{\circ} \mathrm{C} /$ 0.2 Torr, m.p. $32-33^{\circ} \mathrm{C}$, in $45 \%$ yield. $v(\mathrm{Si}-\mathrm{H})\left(\mathrm{CH}_{2} \mathrm{Cl}_{2}\right) 2062 \mathrm{~cm}^{-7}$. NMR $\left(\mathrm{CDCl}_{3}\right)$ : $\mathrm{t}-\mathrm{Bu}, \tau$ 8.85; $\mathrm{H}, \tau$ 6.35. Parent ion at $m / e$ 286. (Found: $\mathrm{C}, 67.00 ; \mathrm{H}$, 13.29. $\mathrm{C}_{16} \mathrm{H}_{38} \mathrm{Si}_{2}$ calcd.: $\mathrm{C}, 67.13 ; \mathrm{H}, 13.28 \%$.)

\section{1,1,2,2-Tetra-t-butyl-1,2-dibromodisilane}

Bromine (6.45 g, $0.040 \mathrm{~mol}$ ) in ca. $50 \mathrm{ml}$ of $\mathrm{CCl}_{4}$ was added dropwise to $\mathrm{H}(\mathrm{t}-\mathrm{Bu})_{2} \mathrm{SiSi}(\mathrm{t}-\mathrm{Bu})_{2} \mathrm{H}(5.8 \mathrm{~g}, 0.020 \mathrm{~mol})$ dissolved in $50 \mathrm{ml}$ of $\mathrm{CCl}_{4}$ at $-20^{\circ} \mathrm{C}$. The mixture was allowed to warm to $25^{\circ} \mathrm{C}$ and then stirred overnight, after which time the solution was yellow. The solvent was removed under vacuum and the residue was recrystallized from petroleum ether $\left(30-60^{\circ} \mathrm{C}\right)$ to give $9.0 \mathrm{~g}(100 \%)$ of $\mathrm{Br}(\mathrm{t}-\mathrm{Bu})_{2} \mathrm{SiSi}(\mathrm{t}-\mathrm{Bu})_{2} \mathrm{Br}, \mathrm{m} . \mathrm{p} .195-197^{\circ} \mathrm{C} . \mathrm{NMR}\left(\mathrm{CDCl}_{3}\right), \tau 8.7$. Parent ion at $m / e$ 444. (Found: $\mathrm{C}, 43.48 ; \mathrm{H}, 8.23 . \mathrm{C}_{16} \mathrm{H}_{36} \mathrm{Br}_{2} \mathrm{Si}_{2}$ calcd.: $\mathrm{C}$, 43.27; $\mathrm{H}, 8.11 \%$.)

Several attempts were made to dehalogenate $\mathrm{Br}(\mathrm{t}-\mathrm{Bu})_{2} \mathrm{SiSi}(\mathrm{t}-\mathrm{Bu})_{2} \mathrm{Br}$ in the presence of conjugated dienes as trapping agents. The following experiment is illustrative.

In a Schlenk tube, $2.0 \mathrm{~g}(4.5 \mathrm{mmol})$ of $\mathrm{Br}(\mathrm{t}-\mathrm{Bu})_{2} \mathrm{SiSi}(\mathrm{t}-\mathrm{Bu})_{2} \mathrm{Br}$ was dissolved in $30 \mathrm{ml}$ of petroleum ether $\left(30-60^{\circ} \mathrm{C}\right)$ and cooled to $-65^{\circ} \mathrm{C}$. $t$-Butyllithium ( $5.15 \mathrm{mmol}, 0.75 \mathrm{M}$ in pentane) was added dropwise over a $10 \mathrm{~min}$ period, but no reaction was apparent. trans, trans-2,4-Hexadiene $(2 \mathrm{ml})$ was then added, and the mixture was allowed to warm to ambient temperature. Still no reaction was cvident, so the mixture was refluxed overnight to give a slight cloudiness. However, concentrating the solution and cooling to $-15^{\circ} \mathrm{C}$ allowed the total recovery of starting dibromide.

Similar experiments with methyllithium, n-butyllithium, and the tetramethylethylenediamine complex of $n$-butyllithium gave identical results. Likewise, no reaction was observed between $\mathrm{Br}(\mathrm{t}-\mathrm{Bu})_{2} \mathrm{SiSi}(\mathrm{t}-\mathrm{Bu})_{2} \mathrm{Br}$ and lithium, sodium, or magnesium amalgams in THF, or between the dibromide and $\mathrm{Na}_{2} \mathrm{Fe}(\mathrm{CO})_{4}$ in THF.

Stirring $(\mathrm{t}-\mathrm{Bu})_{4} \mathrm{Si}_{2} \mathrm{Br}_{2}(0.6 \mathrm{~g})$ with excess, molten potassium in refluxing * cyclohexane for $52 \mathrm{~h}$ gave a green mixture. Filtration of this mixture gave a blue solid and a yellow filtrate, from which a viscous polymeric material was obtained upon removing the solvent. A short-path distillation of the polymer at $93^{\circ} \mathrm{C} / 0.01$ Torr gave a few drops of liquid, identified as a mixture of $(t-B u)_{3}$ $\mathrm{Si}_{2} \mathrm{H}_{3}$ and $(t-\mathrm{Bu})_{3} \mathrm{Si}_{2} \mathrm{H}_{3} \mathrm{O}$ by the GLC-mass spectral technique.

\section{Attempted dehalogenation of $\mathrm{ClMe}_{2} \mathrm{GeGeMe}_{2} \mathrm{Cl}$}

The following experiment is illustrative of several that were performed in an attempt to dehalogenate $\mathrm{Me}_{4} \mathrm{Cl}_{2} \mathrm{Ge}_{2}$.

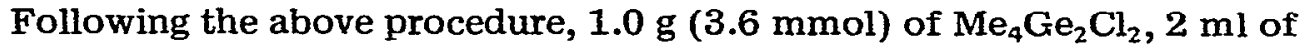
trans, trans-2,4-hexadiene, and $4.5 \mathrm{mmol}$ of $\mathrm{t}$-BuLi were mixed in petroleum ether at $-60^{\circ} \mathrm{C}$. No reaction was evident, so the mixture was allowed to warm slowly, and a precipitate formed as the temperature increased. Upon reaching room temperature, the lithium chloride was filtered off and the solvent removed from the filtrate to give a viscous oil. Short-path distillation at $85^{\circ} \mathrm{C} / 0.01$ Torr gave a mixture which was analyzed by GLC-mass spectrometry. The main com- 
ponent was $\mathrm{Me}_{4}(\mathrm{t}-\mathrm{Bu})_{2} \mathrm{Ge}_{2}$ with ca. one half as much $\mathrm{Me}_{4}(\mathrm{t}-\mathrm{Bu}) \mathrm{HGe}_{2}$. Minor amounts of $\mathrm{Me}_{4}(\mathrm{t}-\mathrm{Bu}) \mathrm{ClGe}_{2}$ and $\mathrm{Me}_{4} \mathrm{H}_{2} \mathrm{Ge}_{2}$ were noted. The results of the GLCmass spectral analysis were corroborated by IR and NMR analysis of the mixture:

\section{References}

1 M.D. Curtis, J. Organometal. Chem., 60 (1973) 63.

2 M: Gumada, M. Ishikawa and S. Maeda, J. Organometal. Chem., 2 (1964) 478.

3 E. Wiberg, O. Stecher, H.J. Andrascheck, L. Kreuzbichler, and E. Staude, Angew. Chem., 75 (1963) 516.

4. M. Kumada, S. Sakamoto and M. Ishikawa, J. Organometal. Chem., 17 (1969) 235.

5 M. Kumada, M. Yamaguchi, Y. Yamamoto, J.-I. Nakajima and K. Shiina, J. Org. Chem., 21 (1956) 1264.

6 E.J. Bulten and J.G. Noltes, Tetrahedron Lett., 29 (1966) 3471.

7 C. Eaborn, W.A. Dutton, F. Glockling and K.A. Hooten, J. Organometal. Chem.. 9 (1967) 175.

8 F. Féher, and P. Plichta, Inorg. Chem., 10 (1971) 609.

9 L.J. Tyler, L.H. Sommer and F.C. Whitmore, J. Amer. Chem. Soc., 70 (1948) 2876.

10 M.P. Doyle and C.T. West. J. Amer. Chem. Soc., 97 (1975) 3777.

11 M.C. Harvey. W.H. Nebergall and J.S. Peake. J. Amer. Chem. Soc. 79 (1957) 2762.

12 M. Weidenbruch and W. Peter, J. Organometal. Chem., 84 (1975) 151.

13 A. Carrick and F. Glockling, J. Chem. Soc. A. (1966) 623.

14 K. Triplett and M.D. Curtis, Inorg. Chem., 14 (1975) 2284.

15 M.P. Brown and G.W.A. Fowles, J. Chem. Soc., (1958) 2811.

16 P. Bondjouk and R. West, J. Amer. Chem. Soc., 95 (1973) 3983. 